\title{
Youth Policy Practice in Post-Soviet Russia and Belarus: Past and Present ${ }^{1}$
}

\author{
K. SILVAN*
}

\begin{abstract}
*Kristina Silvan - PhD Candidate in Political History, University of Helsinki, Finland. Address: Snellmaninkatu 14 A, 00014, University of Helsinki, Helsinki, Finland. E-mail: kristiina.silvan@helsinki.fi

Citation: Silvan K. (2019) Youth Policy Practice in Post-Soviet Russia and Belarus: Past and Present. Mir Rossii, vol. 28, no 1, pp. 161-171.DOI: 10.17323/1811-038X-2019-28-1-161-171
\end{abstract}

This article examines the changes and continuities in youth policy practice in the Russian Federation and the Republic of Belarus from the mid-1980s until the present day. The article finds that while there were notable similarities between Belarus and Russia in the early 1990s, the practice of youth policy has since developed distinctively in the two countries, with Belarus currently demonstrating a mass organization model and Russia a complex model of youth policy practice. The focus on a patriotic upbringing and an approach that tends to ignore young people's agency are recognized as features that stem from the two countries' shared Soviet past and their present authoritarian tendencies and thus distinguish the Belarusian and Russian approaches to youth policy practice in comparison with other countries, although the aim of youth policy, to bring up "ideal citizens", remains universal.

Key words: youth policy, youth organizations, policy practice, Belarus, Russia, process tracing, contemporary history

\section{Introduction}

This article analyses the development of the practice of youth policies in Belarus and Russia after the collapse of the Soviet Union up until the present day. In addition

\footnotetext{
1 This article was written while working in a project "Multilayered Borders of Global Security" (GLASE), funded by
} the Strategic Research Council (STN) at the Academy of Finland, decision numbers 303480 and 303529. 
to exploring and explaining similarities and differences between the two countries, the article points out changes and continuities in the youth policy arena of the post-Soviet space. Moreover, the application of the theoretical framework of youth policy literature allows the article to ask what - if anything - is unique about the post-Soviet youth policy practice.

The analysis of the qualitative study is based on diverse and triangulated research data that combines secondary literature with press articles and interviews conducted by the author with youth policy practitioners. The article examines the practice of youth policy chronologically from the era of perestroika up until the present day.

The article argues that despite similar challenges in the arena of youth, different systems of youth policy practice have developed in the Republic of Belarus and the Russian Federation. This dissimilarity cannot be explained by the shared communist past but, as the process-tracing of the article demonstrates, as a result of different preferences among youth policy makers.

The aim of youth policy, to raise "ideal citizens", is universal and can be recognized in both Belarus and Russia. Yet the approach to youth policy, and consequently its practice, differs between these two cases. In Belarus, youth policy is exercised primarily through educational institutes and the Belarusian Republican Youth Union, whereas in Russia, various mechanisms are in place. The Russian approach to youth policy is therefore characterized by complexity: educational institutes, youth organizations, and other platforms of engagement, such as youth forums, are all important components of the youth policy practice, whereas the Belarusian practice relies heavily on one government-affiliated mass membership youth organization.

Despite the differences, there are also similarities between Belarusian and Russian youth policy practice. In both countries, the challenge is that policy measures touch only a small group of young people, the so-called "future elites". Moreover, as this article demonstrates, the hands-on approach of youth policy practice can drive some young people to disengagement and reluctance to participate. To overcome these and other challenges, new and innovative approaches to youth policy practice are needed both today and in the future.

The article focuses first and foremost on the supportive policy measures carried out by the Belarusian and Russian governments in the arena of youth policy. It therefore excludes the analysis of the measures employed by the state in order to prevent and limit those forms of young people's public behavior that are perceived as harmful, such as participating in anti-government rallies (see, for example, [Gel'man 2016]). Due to the complexity of the issue, the analysis of this side of the Russian and Belarusian youth policy is left for further researchers.

\section{What is youth policy and how is it practiced?}

The literature on youth policy is multi-disciplinary, however it has its roots in psychology and sociology. As policy can be defined as a state or government response to an issue or problem that requires attention [Birkland 2001], it is not surprising that the early youth policy literature, in particular, was focused on young people's problems and problematicness in society [Griffin 1997]. Up until today, "resolving issues" in the youth 
sphere has been considered especially important because young people are seen as the future of society. History is full of short- or long-lived youth policy campaigns aimed at putting young people's development on what policy makers think is the right track (for an overview of twentieth century Germany, for example, see [Saunders 2006]).

While the need for youth policy has never properly been challenged in the academic literature or among policy practitioners, there has been a clear shift in what is considered to make youth policy measures effective. The traditional paradigm of youth policy portrayed young people as vulnerable members of the society that could live up to their potential only if their development was supported by measures drafted by adults. This traditional paradigm therefore assumed young people as passive policy objects [Loncle 2012]. However, in the 1970s some scholars and practitioners started to argue that youth policy could be more effective if young people themselves had some agency in the policy process. This view had become widely accepted by the 1990s, when 'participation' became a buzzword in public policy as a whole, and in youth politics in particular [Mørch 2005, p. 33]. While debate on the nature of participation and agency is still ongoing, the idea that young people ought to be somehow involved in the policy process if youth policy is to be effective is no longer challenged [Munglia 2012].

The rise of the new participatory paradigm has driven the redefinition of roles in youth policy. Whereas earlier the policy-makers were the ones to (actively) design and implement policy, young people would act solely as the (passive) receivers of policy measures [Silvan (4) 2018]. The role of youth organizations would be determined according to their nature: movements and organizations that were set up and managed by adults would be included in the process of policy making and execution, while youthled organizations would be more likely be allocated the role of (passive) policy objects [Silvan (3) 2018]. In today's world, however, there are attempts to allocate an active role in policy practice to young individuals [Laine, Gretschel 2009]. The role of youth organizations as policy practitioners has, on the other hand, become crucial as they represent a middle ground between policy makers and young people.

An important feature of youth policy practice is its temporal and regional contextuality. Even in the era of globalization, each country can decide how it will define youth policy and what kind of measures are preferred as a part of it. As a result, a country's youth policy always mirrors how a government looks at its young citizens [Council of Europe 2018]. The comparative analysis of Russian and Belarusian youth policy practices confirms this view. While sometimes the choice of policy measures can be explained by specific local challenges, in some cases the practice of youth policy is determined by tradition, following the logic of path dependency [North 1990, p. 94].

The lack of a clear definition of youth policy has led some authors to the hasty conclusion that there are states without youth policy. For example, one report stated that if there was no "policy, strategy or law", there could also be no talk of youth policy [Youth Policy Press 2014, p. 8]. In another instance, two authors claimed that Belarus has only been implementing a youth policy since 1991 [Sechko, Romanova 2017, p. 86]. Following the mainstream public policy literature, this article argues that as long as there are state institutions capable of drafting and implementing policy regarding some societal group, policy does exist, whether it is explicitly formulated or not [Birkland 2001]. Focus on youth policy practice rather than its official formulation further explains and supports the broad conceptual approach of this article. 


\section{Perestroika and the immediate post-Soviet approach to youth policy}

A brief overview of the Soviet youth policy cannot be omitted if one hopes to understand the development of youth policy practice in Belarus and Russia in the post-Soviet era. In the Soviet party-state, youth policy was practiced by the government via two main channels: educational institutes and Komsomol, the Communist Youth League. Although Komsomol was officially portrayed as an independent youth organization reflecting the needs and interests of young people [Reshetov, Skurlatov 1977, pp. 39-41], as an organization managed by the communist party, it was rather an "organ of social control" in the youth sphere [Pilkington 2002 [1994], p. 79].

However, during the years of perestroika, the relationship between the state, youth and Komsomol began to change. First, starting from around 1986, the policy of glasnost' allowed public discussion of informal youth groups and their problems [Pilkington 2002 [1994], pp. 116-117]. Secondly, Komsomol was harshly criticized for failing at the task of (moral) upbringing [Silvan (3) 2018]. As a result there was an attempt to reform Komsomol, which led to the redefinition of its role as a "defender of youth interests" rather than the party's mouthpiece in the youth sphere [Pilkington 2002 [1994], p. 169].

Perestroika and the subsequent redefinition of Komsomol's role enabled the passing of the first (and last) Soviet law on youth. There had been attempts to draft such legislation in the 1960s and 1970s, but these early endeavors had not been successful [Lukov 2006, p. 220]. The drafting of the "Law on the Fundamental Principles of State Youth Policy" took four years and was finally passed in 1991, right before the collapse of the Soviet Union [Il'inskij 2009, pp. 118-121]. While the aim of this article is not to track the development of youth policy legislation, the law on youth cannot be ignored as it initiated the establishment of youth affairs committees, and state organs responsible for the practice of youth policy in the regions. While the collapse of the USSR invalidated the law on youth, these committees continued to exist and function in the newly established Russian Federation (see, for example, [Istoriya komiteta po molodezhnoj politike 2018]).

In the aftermath of the August putsch of 1991, the All-Union Komsomol made the decision to dissolve, while the Russian Komsomol was renamed the Russian Youth Union (Rossijskij soyuz molodezhi) and due to the mass exodus of its members became a marginal player in Russian youth policy. A similar development took place in the Republic of Belarus, where the legacy organization of Komsomol would be called the Belarusian Youth Union (Soyuz molodezhi Belarusi, later renamed the Belarusskij soyuz molodezhi) [Silvan (2) 2018]. In the immediate post-Soviet era, the arena of youth organizations was filled with associations and movements that could be characterized as informal and unstructured [Evans, Henry, Sundstrom 2005; Zinchenko 2016].

The early 1990s marked a period when neither the Russian nor the Belarusian government perceived youth high on the policy agenda [Henderson 2011, pp. 14-18; Silvan (2) 2018]. Indeed, the vacuum created by the disappearance of Komsomol coupled with the lack of state funding for youth projects and organizations created a situation where it was possible to talk about weak and inconsistent youth policy practice. At the beginning of the 1990s, contemporaries would talk about a "lost generation" that the state had abandoned [Pilkington 2002 [1994], p. 193]. 


\section{The mass membership organization model of youth policy practice}

After the initial years of youth policy negligent, youth would emerge as a policy issue in Belarus in the mid-1990s and in Russia in the early 2000s. This section discusses the (re)-appearance of the mass youth organization model in youth policy practice in Belarus and Russia. In both countries, the model emerged as the government's response to what it perceived as the political and social challenges faced by its young citizens. As this paper argues, the model did not appear from nowhere; it reflected both the communist past and the semi-authoritarian present of the two countries.

President of Belarus Lukashenko was the first to draw attention to the practice of youth policy and the role of young people in 1996, when talking at the Youth Forum, an event organized by the government for youth organization and movement representatives. He declared that youth as the "most progressive part of the society" ought to officially voice its support for the upcoming referendum on the constitution [Lukashenko 1996]. As the participants of the forum opted not to issue a declaration of such a political nature, Lukashenko went on to initiate the establishment of the Belarusian Patriotic Youth Union (Belarusskij patrioticheskij soyuz molodezhi, BPYU) which quickly became the biggest player in the youth policy arena [Gushtyn 2016]. The youth policy budget allocated by the state committee of youth affairs for youth policy practice was directed primarily to the BPYU, and, after the organization merged with the Belarusian Youth Union in 2002, to its successor, the Belarusian Republican Youth Union (Belarusskij respublikanskij soyuz molodezhi, BRYU) [Silvan (2) 2018 ].

A similar development took place in Russia from the early 2000s onwards, although due to Russia's geographical size and de-centralized federative model the change was not as encompassing as in Belarus. The first attempt to set up a pro-government, government-supported mass membership organization for youth was the establishment of the youth movement Walking Together (Idushchie vmeste), reconstructed as Nashi in 2005 [Mijnssen 2012]. Both organizations were funded directly from the Kremlin until 2008, when a new Federal Youth Affairs Agency (Federal'noe agentstvo po delam molodezhi or FADM 'Rosmolodezh') was set up [Silvan 2017]. However, unlike in Belarus where the youth policy budget was directed almost entirely to the BRYU, in Russia the state would also financially support youth organizations other than Nashi, such as the Russian Youth Union [Silvan (3) 2018].

The reason why it makes sense to talk about a similar mass organization model of youth policy practice is because both the BRYU and Nashi (and their predecessors) were established with the support of the government to respond to challenges in the youth sphere. The remedy dubbed patriotic upbringing (patrioticheskoe vospitanie) would include the promotion of healthy lifestyles, loyalty to the state, and an "active civic stance" [Omelchenko, Maximova, Noyanzina, Goncharova, Avdeeva 2015]. Successful youth policy practice would mean the promotion of patriotism among young citizens while the failure of the policy would be demonstrated by alcoholism, drug use, participation in anti-government demonstrations and a "passive" stance regarding the challenges faced by the state in the $21^{\text {st }}$ century. This focus on upbringing was a hands-on approach to youth policy practice that echoed both the Soviet approach to youth policy and the challenges faced by the semi-authoritarian government. 
A key role in the mass organization model of youth policy practice is played by the government-affiliated youth organization (or a limited number of organizations). The organization functions as the state's channel of policy implementation in the youth sphere. While putting policy into practice is considered by the policy makers to be more efficient through non-governmental organizations than state representatives, the urge to hold the reins limits the number of supported organizations to only the one or few the government believes it can trust with the challenging task of raising the youth.

\section{A multi-platform model of youth policy practice}

In Belarus, youth policy is still carried out by the state-affiliated BRYU, but in Russia, the 2010s have witnessed the demise of Nashi and the development of a more varied approach to youth policy practice. While analyzing the reasons behind Nashi's disintegration lies beyond the scope of this article, it is important to note that by 2012 policy makers concluded that Nashi was not managing to deal with the challenges in the youth sphere effectively enough and that new forms of youth policy practice should be introduced [Author's interviews with former top level Nashi activists Iliya and Maksim², Moscow, May 2018]. Although in Belarus the BRYU has been subject to harsh criticism, too [Burov 2018], generous government support continues.

What are the new forms of youth policy practice that have been introduced in Russia in recent years? First and foremost, while the underlying task has remained unaltered, there has been a quest to engage with young citizens in various ways. In addition to supporting the work of youth organizations, the government has provided more agency for Rosmolodezh', by upgrading its status from a sub-committee of the Ministry of Education and Science to an independent committee operating directly under the auspices of the government [Tovkailo, Mukhametshina, Churakova, Bocharova 2018]. The repertoire of youth policy practice promoted by Rosmolodezh'varies from youth forums to competitions for individuals and organizations alike. What is more, the agency is actively seeking new ways to reach out to young people [Author's interview with Aleksei and Sergei, both Rosmolodezh'employees. Moscow, May 2018]; however, it remains difficult to say how successful this reaching out really is.

\section{Conclusion: Similar challenges, different approaches?}

Compared to the model of implementing youth policy through one or a few governmentaffiliated youth organizations, one can assume that the complex model of youth policy practice in place in today's Russia is more effective as it takes into consideration a variety of young citizens' interests better. The fact that in Belarus new youth policy practices are sought only inside the BRYU is a factor that essentially impedes the effectiveness of youth policy practice due to the organization's negative public image [Silvan (1) 2018].

2 All names have been changed to protect the anonymity of the interviewées. 
The unyielding support of the Belarusian government to the BRYU is what has halted the development of new forms of youth policy practice in recent years.

While contemporary approaches to youth policy practice differ in contemporary Belarus and Russia, the two also share similarities that set them apart from other countries. Most importantly, both countries explicitly stress the importance of a patriotic upbringing that (either consciously or unconsciously) downplays the importance of youth agency through participation. As this article has argued, the focus on upbringing mirrors both the legacy of Soviet youth policy and the current authoritarian tendencies of the Belarusian and Russian governments which in practice translates into a hands-on approach and a desire to control the youth sphere.

Youth policy practice in both countries tends to address only young citizens identified by policy makers as "future elites". While the need to limit government support to the gifted few is explained as the result of budget constraints [Author's interview with Aleksei], the tendency might create challenges in the future. In addition, the reluctance to provide young people room for agency means that some young people are prone to resist policy measures either actively or passively and, as a result, the scope of the policies and their effectiveness diminishes. However, getting the entire young generation on board is crucial in order to meet the complex challenges that face the two countries in the $21^{\text {st }}$ century. While the desire to support the development of an ideal citizen is universal, there are more and less efficient ways to implement it in practice.

\section{References}

Birkland T.A. (2001) An Introduction to the Policy Process: Theories, Concepts, and Models of Public Policy Making, Armonk, N.Y: M.E. Sharpe.

Burov N. (2018) Chto stoit za kadrovymi izmeneniyami v rukovodstve OO «BRSM»? [What Stands Behind the Personnel Changes in the Leadership of the NGO "BRSM"?]. Nashe mnenie, June 6, 2018.Available at: https://nmnby.eu/news/analytics/6627.html, accessed 14.01.2019.

Council of Europe (2018). About Youth Policy. Available at: https://www.coe.int/en/web/youth/about-youth-policy, accessed 14.01.2019.

Evans A.B., Henry L.A., Sundstrom L.M. (eds.) (2005) Russian Civil Society: a Critical Assessment, Armonk, N.Y.: M.E. Sharpe.

Gel'man V. (2016) The Politics of Fear: How Russia's Rulers Counter their Rivals. Russian Politics, vol. 1, no 1, pp. 27-45.

Griffin C. (1997). Representations of the Young. Youth in Society (eds. Roche J., Tucker S.), London: SAGE and the Open University, pp. 10-18.

Gushtyn A.Y. (2016) "Nechego rabochemu lezt' v politiku”. Prostye lyudi o referendume-1996 ["No Need for a Worker to Mess with Politics". Ordinary People on the Referendum-1996]. Naviny.by, November 24, 2016. Available at: https://naviny.by/article/20161124/1479977605nechego-rabochemu-lezt-v-politiku-prostye-lyudi-o-referendume-1996, accessed 14.01.2019. Henderson S.L. (2011) Civil Society in Russia. Problems of Post-Communism, vol. 58, no 3, pp. 11-27.

Il'inskij I.M. (2009) Obrazovanie, molodezh', chelovek [Education, Youth, Individual], Moscow: Izdatel'stvo Moskovskogo gumanitarnogo universiteta.

Istoriya komiteta po molodezhnoj politike $\mathrm{i}$ vzaimodehstviyu $\mathrm{s}$ obshchestvennymi organizatsiyami [History of the Committee on Youth Policy and Interaction with Public Organizations] (2018). The Government of Saint-Petersburg. Available at: https://kpmp.gov.spb.ru/o-komitete/istoriya-komiteta/, accessed 14.01.2019. 
Laine S., Gretschel A. (2009) Whose Arena is the EU Youth Policy? Young Participants' Involvement and Influence in the EU Youth Policy from Their Own Points of View: Case of the EU Presidency Youth Event in Hyvinkää, Finland. Young, vol. 17, no 2, pp. 191-215.

Loncle P., Leahy P., Munglia V., Walther A. (2012) Youth Participation: Strong Discourses, Weak Policies - a General Perspective. Youth Participation in Europe (eds. Munglia V., Cuconato M., Loncle P., Walther A.), Bristol, UK: Policy Press, pp. 21-38.

Lukashenko A. (1996) Speech at the Forum of Youth of Belarus, Minsk.

Lukov V.A. (2006) Zakon o molodezhi [Law on Youth]. Znanie. Ponimanie. Umenie, no 2, pp. 219-221.

Mijnssen I. (2012) The Quest for an Ideal Youth in Putin's Russia, Stuttgart: Ibidem-Verlag.

Mørch S. (2005) Researching Youth Life. Mixed Methods in Youth Research (ed. Helve H.), Helsinki: Finnish Youth Research Society, pp. 29-56.

Munglia V., Cuconato M., Loncle P., Walther A. (2012) The Analysis of Youth Participation in Contemporary Literature: a European Perspective. Youth Participation in Europe: Beyond Discourses, Practices and Realities (eds. Loncle P., Cuconato M., Munglia V., Walther A.), Bristol: Policy Press, pp. 1-18.

North D. (1990) Institutions, Institutional Change and Economic Performance, Cambridge: Cambridge University Press.

Omelchenko D., Maximova S., Noyanzina O., Goncharova N., Avdeeva G. (2015) National Identity and Patriotism among Russian Youth: Representations, Feelings and Actions. Asian Social Science, vol. 11, no 6, pp. 27-36.

Pilkington H. (2002 [1994]) Russia's Youth and its Culture: A Nation's Constructors and Constructed, London: Taylor \& Francis.

Reshetov P., Skurlatov V. (1977) Soviet Youth - A Socio-Political Outline, Moscow: Progress Publishers.

Saunders A. (2006) 'Who Has the Youth, Has the Future': Three Youth Movements in TwentiethCentury Germany. Journal of Contemporary History, vol. 41, no 1, pp. 175-183.

Sechko N., Romanova S. (2017) Effectiveness of Youth Policy Model in Belarus at the Contemporary Stage of Development. Management Theory and Studies for Rural Business and Infrastructure Development, vol. 39, no 1, pp. 86-99.

Silvan K. (2017) Patriotic Pluralism: Russian Pro-Government Youth NGOs as Executors of State Youth Policy. Aleksanteri Conference, Helsinki, pp. 1-12.

Silvan K. (1) (2018) (Dis)engaging Youth in Contemporary Belarus Through a Pro-Presidential Youth League. Manuscript submitted for publication.

Silvan K. (2) (2018) From Komsomol to the Republican Youth Union: Building a pro-Presidential Mass Organisation of Youth in post-Soviet Belarus. Europe-Asia Studies (in press).

Silvan K. (3) (2018) An Organisation for Youth: The Establishment and the Development of the Russian Youth Union (1990-2018). Evropa i Evropejskij soyuz glazami uchenykh [Europe and the European Union through the Eyes of Scholars] (ed. Deriglazova L.), Tomsk: Tomsk State University Press, pp. 81-96.

Silvan K. (4) (2018) Policy Subjects or Objects? Paradigm Shift in the Youth Policy of Belarus. Vesnik of Yanka Kupala State University of Grodno. Series 5. Economics. Sociology. Biology, vol. 8, no 3, pp. 67-79

Tovkailo M., Mukhametshina E., Churakova O., Bocharova S. (2018) Putin poruchil Medvedevu zanyat'sya molodezhnoj politikoj [Putin Instructed Medvedev to Engage in Youth Policy]. Vedomosti, May 15, 2018 Available at: https://www.vedomosti.ru/politics/ articles/2018/05/15/769587-putin-poruchil-medvedevu-zanyatsya-molodezhnoi-politikoi, accessed 14.01.2019.

Youth Policy Press (2014). The State of Youth Policy in 2014, Berlin: Youth Policy Press. Available at: http://www.youthpolicy.org/library/wp-content/uploads/library/2014_State_ Youth_Policy_2014_En.pdf, accessed 14.01.2019.

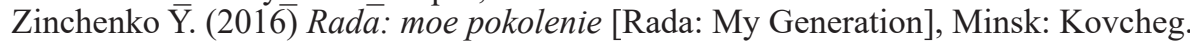




\title{
Практика молодежной политики в Российской Федерации и Республике Беларусь после распада Советского Союза
}

\author{
К. СИЛВАН*
}

\begin{abstract}
*Кристина Силван - аспирант, Университет Хельсинки, Финляндия Адрес: Snellmaninkatu 14 A, 00014, University of Helsinki, Helsinki, Finland. E-mail: kristiina.silvan@helsinki.fi
\end{abstract}

Цитирование: Silvan K. (2019) Youth Policy Practice in Post-Soviet Russia and Belarus: Past and Present. Mir Rossii, vol. 28, no 1, pp. 161-171. DOI: $10.17323 / 1811-038 X-2019-28-1-161-171$

В статье анализируются особенности молодежной политики в Российской Федерации и Республике Беларусь начиная с перестройки до настоящего времени; рассматриваются сходства и различия, изменения и преемственность этого направления государственной стратегии в двух странах. Следует подчеркнуть, что исследовательский интерес автора сосредоточен не на законодательной базе молодежной политики, а на ее конкретном воплощении в жизнь.

Применение теоретических рамок, описанных в зарубежной литературе, позволяет выяснить уникальность в проведении молодежной политики в России и Беларуси. Качественный анализ основан на выстроенных в хронологическом порядке триангулированных данных, взятых из исследовательских источников, статей в СМИ и интервью автора с молодыми людьми и представителями государственных органов, курирующими вопросы молодежной политики. Основное внимание уделяется мерам, которые принимаются правительствами России и Беларуси в сфере молодежной политики с целью мобилизации и консолидации молодежи. Необходимо оговориться, что шаги, предпринимаемые государствами для предотвращения и ограничения противозаконного поведения молодых людей (например, участия в антиправительственных митингах), в настоящем исследовании не рассматриваются.

В статье констатируется, что научную литературу, посвященную молодежной политике, можно разделить на две группы. В работах, основанных на традиционной парадигме, акцент делается на важности воспитания и решения проблем в молодежной сфере силами старшего поколения. Другой, более распространенный на сегодняшний день подход демонстрирует, что этот вектор государственного курса может стать эффективным только при условии включенности молодежи в разработку и реализацию молодежной политики.

Автор утверждает, что, несмотря на аналогичные для двух стран вызовы в области молодежной политики, в Российской Федерации и Республике Беларусь сложились различные схемы претворения в жизнь этого государственного курса. В Беларуси молодежная политика осуществляется в основном через образовательные учреждения и молодежную организацию «Белорусский республиканский союз молодежи», тогда как в России действуют более сложные механизмы: на увеличение вовлеченности молодежи нацелены и образовательные институты, и молодежные организации, и многочисленные форумы. В статье констатируется, 
что такая несхожесть практик в России и Беларуси не может быть объяснена ни особенностями исторического развития, ни разновекторностью в вызовах в сфере молодежной политики этих стран - она является результатом специфики представлений и предпочтений чиновников двух стран, в зону ответственности которых входит проведение государственного курса в сфере молодежной политики.

И все же, несмотря на выявленные различия, при сравнении с ситуацией в других государствах молодежная политика в России и в Беларуси характеризуется очевидным сходством: в обеих странах большое внимание уделяется воспитанию молодых людей, но при этом активную роль играет не сама молодежь, а представляющие ее организации, которые зачастую возглавляются представителями старшего поколения, что отвращает молодых людей от участия в мероприятиях и снижает эффективность молодежной политики. Более того, и в Российской Федерации, и в Республике Беларусь она касается в первую очередь небольшой группы молодых людей - так называемой будущей элиты.

В статье делается вывод о том, что для преодоления современных вызовов необходимы новые подходы к проведению молодежной политики, и в этой ситуации изучение опыта молодежной политики в других странах может явиться хорошим источником для подобных инновационных идей. В целом основная задача молодежной политики - воспитание «идеальных граждан» - является универсальной, и заметные различия возникают только в сфере реализации.

Ключевые слова: молодежная политика, молодежные организации, практика молодежной политики, Республика Беларусь, Российская Федерация, современная история

\section{Литература}

Буров Н. (2018) Что стоит за кадровыми изменениями в руководстве ОО «БРСМ»? // Наше мнение. 6 июня $2018 / /$ https://nmnby.eu/news/analytics/6627.html

Гуштын А.Ю. (2016) «Нечего рабочему лезть в политику». Простые люди о референдуме-1996 // Naviny.by. 24 ноября 2016 // https://naviny.by/article/20161124/1479977605nechego-rabochemu-lezt-v-politiku-prostye-lyudi-o-referendume-1996

Зинченко Я. (2016) Рада: мое поколение. Минск: Ковчег.

Ильинский И.М. (2009) Образование, молодежь, человек. М.: Издательство Московского гуманитарного университета.

История комитета по молодежной политике и взаимодействию с общественными организациями (2018) // Правительство Санкт-Петербурга // https://kpmp.gov.spb.ru/o-komitete/istoriya-komiteta/

Луков В.А. (2006) Закон о молодежи // Знание. Понимание. Умение. № 2. С. 219-221.

Товкаило М., Мухаметшина Е., Чуракова О., Бочарова С. (2018) Путин поручил Медведеву заняться молодежной политикой // Ведомости. 15 мая 2018 // https://www.vedomosti.ru/politics/articles/2018/05/15/769587-putin-poruchil-medvedevuzanyatsya-molodezhnoi-politikoi

Birkland T.A. (2001) An Introduction to the Policy Process: Theories, Concepts, and Models of Public Policy Making, Armonk, N.Y: M.E. Sharpe.

Council ofEurope(2018)//AboutYouthPolicy//https://www.coe.int/en/web/youth/about-youth-policy 
Evans A.B., Henry L.A., Sundstrom L.M. (eds.) (2005) Russian Civil Society: a Critical Assessment, Armonk, N.Y.: M.E. Sharpe.

Gel'man V. (2016) The Politics of Fear: How Russia's Rulers Counter their Rivals // Russian Politics, vol. 1 , no 1 , pp. 27-45.

Griffin C. (1997). Representations of the Young // Youth in Society (eds. Roche J., Tucker S.), London: SAGE and the Open University, pp. 10-18.

Henderson S.L. (2011) Civil Society in Russia // Problems of Post-Communism, vol. 58, no 3, pp. 11-27.

Laine S., Gretschel A. (2009) Whose Arena is the EU Youth Policy? Young Participants' Involvement and Influence in the EU Youth Policy from Their Own Points of View: Case of the EU Presidency Youth Event in Hyvinkää, Finland // Young, vol. 17, no 2, pp. 191-215.

Loncle P., Leahy P., Munglia V., Walther A. (2012) Youth Participation: Strong Discourses, Weak Policies - a General Perspective // Youth Participation in Europe (eds. Munglia V., Cuconato M., Loncle P., Walther A.), Bristol, UK: Policy Press, pp. 21-38.

Lukashenko A. (1996) Speech at the Forum of Youth of Belarus, Minsk.

Mijnssen I. (2012) The Quest for an Ideal Youth in Putin's Russia, Stuttgart: Ibidem-Verlag.

Mørch S. (2005) Researching Youth Life // Mixed Methods in Youth Research (ed. Helve H.), Helsinki: Finnish Youth Research Society, pp. 29-56.

Munglia V., Cuconato M., Loncle P., Walther A. (2012) The Analysis of Youth Participation in Contemporary Literature: a European Perspective // Youth Participation in Europe: Beyond Discourses, Practices and Realities (eds. Loncle P., Cuconato M., Munglia V., Walther A.), Bristol: Policy Press, pp. 1-18.

North D. (1990) Institutions, Institutional Change and Economic Performance, Cambridge: Cambridge University Press.

Omelchenko D., Maximova S., Noyanzina O., Goncharova N., Avdeeva G. (2015) National Identity and Patriotism among Russian Youth: Representations, Feelings and Actions // Asian Social Science, vol. 11, no 6, pp. 27-36.

Pilkington H. (2002 [1994]) Russia's Youth and its Culture: A Nation's Constructors and Constructed, London: Taylor \& Francis.

Reshetov P., Skurlatov V. (1977) Soviet Youth - A Socio-Political Outline, Moscow: Progress Publishers.

Saunders A. (2006) 'Who Has the Youth, Has the Future': Three Youth Movements in TwentiethCentury Germany // Journal of Contemporary History, vol. 41, no 1, pp. 175-183.

Sechko N., Romanova S. (2017) Effectiveness of Youth Policy Model in Belarus at the Contemporary Stage of Development // Management Theory and Studies for Rural Business and Infrastructure Development, vol. 39, no 1, pp. 86-99.

Silvan K. (2017) Patriotic Pluralism: Russian Pro-Government Youth NGOs as Executors of State Youth Policy. Aleksanteri Conference, Helsinki, pp. 1-12.

Silvan K. (1) (2018) (Dis)engaging Youth in Contemporary Belarus Through a Pro-Presidential Youth League (in press).

Silvan K. (2) (2018) From Komsomol to the Republican Youth Union: Building a pro-Presidential Mass Organisation of Youth in post-Soviet Belarus // Europe-Asia Studies (in press).

Silvan K. (3) (2018) An Organisation for Youth: The Establishment and the Development of the Russian Youth Union (1990-2018) // Дериглазова Л.В. (ред.) Европа и Европейский союз глазами ученых. Томск: Томский университет. С. 81-96.

Silvan K. (4) (2018) Policy Subjects or Objects? Paradigm Shift in the Youth Policy of Belarus // Vesnik of Yanka Kupala State University of Grodno. Series 5. Economics. Sociology. Biology, vol. 8, no 2, pp. 67-79.

Youth Policy Press (2014). The State of Youth Policy in 2014, Berlin: Youth Policy Press // http://www.youthpolicy.org/library/wp-content/uploads/library/2014_State_Youth_ Policy_2014_En.pdf 